\title{
The CASPASE-8 Insertion/Deletion Polymorphism and Risk of Non-small Cell Lung Cancer
}

\author{
Shanbeh Zienolddiny ${ }^{1, *}$, Kine Martinsen ${ }^{1}, \operatorname{Vidar}_{\text {Skaug }}{ }^{1}$, Per Olav Ekstrøm ${ }^{2}$ and Aage Haugen ${ }^{1}$ \\ ${ }^{1}$ Department of Chemical and Biological Working Environment, Section of Toxicology, National Institute of \\ Occupational Health, N-0033 Oslo, Norway. \\ ${ }^{2}$ Department of Surgical Oncology, The Norwegian Radium Hospital, Montebello, Oslo, Norway. \\ *Corresponding author \\ Shan Zienolddiny \\ Department of Chemical and Biological Working Environment \\ Section of Toxicology \\ National Institute of Occupational Health \\ $\mathrm{N}-0033$ Oslo, Norway \\ Tel.: +4723195100; fax +4723195203 \\ E-mail: shan.zienolddiny@stami.no
}

Received: 28 June 2009; | Revised: 16 August 2009; | Accepted: 15 December 2009

\begin{abstract}
The cysteine-dependent aspartate-specific protease 8 (CASP8) is a key enzyme in the apoptosis and genetic polymorphisms in this gene have been reported to affect the gene expression and its enzymatic activity. A six-nucleotide insertion-deletion polymorphism (-652 6N ins/del, rs3834129) in the CASP8 promoter has been shown to be associated with susceptibility to multiple cancers in the Asian populations. Here we report results of genotyping the CASP8 ins/del polymorphism in non-small cell lung cancer (NSCLC) cases and controls from Norway, all of which are of Caucasian origin. The overall odds ratio for NSCLC was 1.40 (95\% CI, 0.95-2.06). When subjects were grouped according to gender, males carrying del/del genotype had an increased odds ratio for developing NSCLC with an OR of 1.61 (95\% CI, 1.02-2.53, $P=0.039)$. Somatic mutations of the TP53 gene in tumors were also analyzed and the results showed no interaction between alterations in TP53 and the CASP8 polymorphism. These results contradict a protective effect of this polymorphism on lung cancer as it has been reported in the Asian populations. The results are discussed in relation to population and exposure specific effects of this polymorphism.
\end{abstract}

Keywords: CASP8; lung cancer; NSCLC; polymorphism; TP53.

\section{Introduction}

Smoking, exposure to occupational and environmental factors are the major causes of lung

Am. J. Biomed. Sci. 2010, 2(2), 121-128; doi: 10.5099/aj100200121 cancer, but genetic factors may play a role [1]. The cysteine-dependent aspartate-specific proteases (CASPs) are important in apoptotic cell signaling [2]. CASP8 is a key enzyme in this

(c) 2010 by NWPII. All rights reserved. 
pathway and functional polymorphisms in the gene have been reported to affect gene expression and enzyme activity.

Another and very important apoptotic signaling pathway is controlled by the TP53 gene. TP53 encodes a tumor suppressor protein which is activated to prevent carcinogenic effects of DNA damage caused by various DNA damaging agents and carcinogens [3]. Upon activation, TP53 induces apoptosis, cell cycle arrest and promotes DNA repair. The importance of this protein is underlined by the fact the TP53 gene is mutated in more than half of NSCLC tumors and mutation of the gene is considered to be an early event in lung carcinogenesis [4].

A six-nucleotide insertion-deletion polymorphism (-652 6N ins/del, rs3834129) in the CASP8 gene promoter was recently described and reported to be associated with susceptibility to multiple cancers [5]. The del variant abolishes an Sp1 transcription factor binding site and was shown to be associated with decreased RNA levels, lower Caspase- 8 enzyme activity and lower apoptotic activity in $\mathrm{T}$ lymphocytes. Further, this variant was found to be associated with almost $25 \%$ reduced risk (per copy) of lung cancer in a Han Chinese population. The authors also reported a protective effect for the del variant in breast cancer in this Chinese population [5].

Most of the studies on the effects of CASP8 polymorphisms in Caucasian populations have not found evidence for CASP 8 variants to be genetic susceptibility markers for cancer. An analysis of $6 \mathrm{~N}$ ins/del polymorphism in breast, colorectal and prostate cancer cases and controls did not show any influence of the del variant in these cancer types in several Caucasian populations [6-8].

The CASP8 gene is important in regulation of the immune system through controlling the apoptosis of inflammatory $\mathrm{T}$ lymphocytes. We and others have previously shown that certain functional polymorphisms in the immune system genes coding for cytokines may predispose individuals to lung cancer $[9,10]$. To examine the hypothesis whether the ins/del polymorphism in CASP8 is a susceptibility marker for lung cancer, we conducted a case-control study among nonsmall cell lung cancer (NSCLC) cases and controls from Norway, all of which are smokers of Caucasian origin.

\section{Materials and methods}

The details of the ongoing lung cancer study (Table 1) and population have been recently published [11]. Briefly, lung cancer patients were admitted for surgery at the university hospitals in Oslo or Bergen between 1986 and 2001. Diagnosis of lung cancer was confirmed by two pathologists and NSCLC cases were enrolled in the study consecutively whenever practically feasible. Controls were recruited from a general health survey conducted by the National Health Surveys in the Oslo area (HUBRO) of the general population. The purpose of the surveys was to monitor the health status of the general population. A total of 440 smokers without any known history of cancer were randomly selected and frequency matched with the cases on age, smoking dose (pack-years) and sex. Cases and controls were interviewed by trained health personnel using questionnaires containing comparable information on demographic and lifestyle details. All subjects gave written consent to participate in the study which was approved by the Regional Ethical Committee.

DNA was extracted from whole blood or normal lung tissue with standard proteinase $\mathrm{K}$ digestion and phenol/chloroform extraction. The CASP8 6bp -652 ins/del was genotyped by capillary fragment length analysis as described elsewhere [12]. A representative picture showing fragment analysis of three subjects with ins/del, $\mathrm{del} / \mathrm{del}$ and ins/ins genotypes, respectively, is shown in Figure 1. There was 99\% genotyping success rate in both cases and controls and no deviation from Hardy-Weinberg equilibrium was observed $(P>0.05)$. A $10 \%$ blinded replicate samples were re-genotyped with a concordance rate of $100 \%$. There were 272 lung tumor specimens available for analysis of mutations in exons 4-9 of the TP53 gene. Mutational analysis was performed as described in a recent publication from our group [13].

Differences in demographic variables, smoking and grouped genotypic frequencies between cases and controls were evaluated by $\chi^{2}$ 
test and reported $P$ values are two-sided with $\mathrm{P}$ $<0.05$ considered as significant. Odds ratios (ORs) and $95 \%$ confidence intervals (CIs) were estimated from unconditional logistic regression analyses using the SPSS (version 15.0) with age, sex and pack-years as covariates using ins/ins as reference.
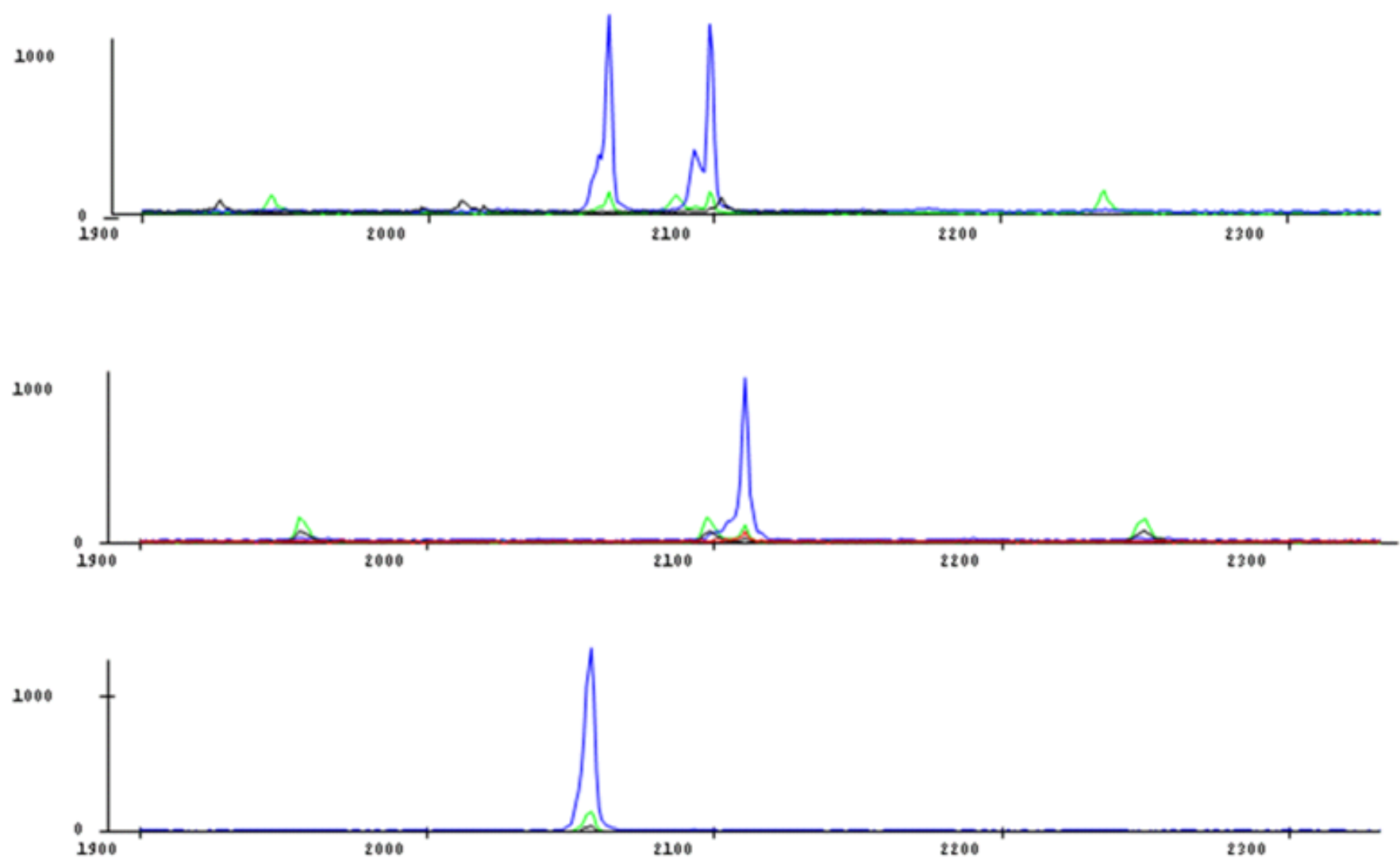

Figure 1. Representative flurogram from CASP8 genotyping showing ins/del heterozygote (top); del/del homozygote (middle) and ins/ins homozygote (bottom).

\section{Results}

The observed frequency of $d e l$ variant was 0.47 in controls and 0.51 in cases whereas the frequency of ins allele was 0.53 in controls and 0.49 in cases, respectively (Table 2) and are in agreement with frequencies in other Caucasian populations [6,7]. Male subjects with homozygote del/del genotype had an increased risk of NSCLC with an odds ratio of $1.61(95 \% \mathrm{CI}, 1.02-2.53, P=$ $0.039)$ after adjustment for age and smoking (Table 2). The OR for male subjects carrying at least one deletion allele $(\mathrm{ins} / \mathrm{del}+\mathrm{del} / \mathrm{del})$ was 1.43 (95\% CI, 1.0-2.06, $P=0.05$ ). There was no association between CASP8 genotypes and
NSCLC histological subtypes of adenocarcinoma, squamous cell carcinoma and large cell carcinoma (Table 2). The risk was neither modified by smoking dose, light smokers ( $\leq 20$ pack-years), moderate smokers ( $>20 \leq 40$ pack-years) and heavy smokers (>40 pack-years) nor smoking status (current/former smokers, data not shown).

TP53 mutational data for 272 lung tumors were analyzed. Lung cancer cases were grouped into two groups either having a TP53 mutation in the tumor or TP53 wild-type and the risk associated with the CASP8 genotypes was compared with healthy controls. The results showed no significant interaction between TP53, 
CASP8 ins/del polymorphism and risk of NSCLC

(Table 2).

Table 1. Characteristics of lung cancer patients and healthy controls

\begin{tabular}{llll}
\hline Parameter & Cases & Controls & $P$ \\
& $\mathrm{~N}=442$ & $\mathrm{~N}=440$ & \\
\hline & & & \\
Median age (min - max) & $66(31-85)$ & $335 / 105$ & $0.40^{*}$ \\
$\begin{array}{l}\text { Sex (male/female) } \\
\text { Number of cigarettes per day }\end{array}$ & $325 / 116$ & & \\
Mean \pm SD & $15.52 \pm 8.21$ & $14.59 \pm 6.29$ & $0.368^{\dagger}$ \\
Median (min.-max) & $14.0(2-60)$ & $15.00(3-40)$ & \\
Total smoking years & & & \\
Mean \pm SD & $41.07 \pm 12.03$ & $42.30 \pm 8.45$ & \\
Median (min.-max.) & $42.00(2-69)$ & $41.00(15-65)$ & \\
Total pack-years & & & \\
Mean \pm SD & & $31.18 \pm 15.07$ & \\
Median (min - max) & $31.41 \pm 17.58$ & $28.50(5-84)$ & \\
& $28.50(1-113)$ & & \\
TP53 status & $\mathrm{n}=272(100 \%)$ & & \\
Mutated & $151(55.5 \%)$ & & \\
Wild-type & $121(44.5 \%)$ & & \\
Histological details & $\mathrm{n}=442$ & & \\
Adenocarcinoma & 159 & & \\
Squamous cell carcinoma & 192 & & \\
Large cell carcinoma & 71 & & \\
NSCLC (not classified otherwise) & 20 & & \\
\hline
\end{tabular}

*The two-sided $\mathrm{P}$ value was calculated from a 2x2 table using Pearson chi-square test.

†The two-sided P values were obtained from Wilcoxon’s non-parametric test for two independent groups. 
Table 2. Frequency of CASP 8 polymorphism in NSCLC cases and controls

\begin{tabular}{|c|c|c|}
\hline Gene/polymorphism & Controls/cases ${ }^{*}$ & Odds ratio $(95 \% \mathrm{CI})^{7}$ \\
\hline \multicolumn{3}{|c|}{ CASP8 (-652 ins/del, rs3834129) } \\
\hline ins/ins & $125 / 107$ & 1.0 \\
\hline ins/del & $210 / 212$ & $1.22(0.87-1.70)$ \\
\hline del/del & $101 / 118$ & $1.40(0.95-2.06)$ \\
\hline ins/del+del/del & $311 / 330$ & $1.28(0.93-1.75)$ \\
\hline \multicolumn{3}{|l|}{ Males } \\
\hline ins/ins & $104 / 80$ & 1.0 \\
\hline ins/del & $159 / 159$ & $1.36(0.92-1.99)$ \\
\hline del/del & $69 / 80$ & $1.61(1.02-2.53) \mathrm{P}=0.039$ \\
\hline ins/del+del/del & $228 / 239$ & $1.43(1.0-2.06) \mathrm{P}=0.050$ \\
\hline \multicolumn{3}{|l|}{ Females } \\
\hline ins/ins & $32 / 27$ & 1.0 \\
\hline ins/del & $51 / 51$ & $0.71(0.34-1.48)$ \\
\hline del/del & $21 / 38$ & $0.73(0.33-1.62)$ \\
\hline ins/del+del/del & $72 / 89$ & $0.72(0.36-1.43)$ \\
\hline \multicolumn{3}{|l|}{ TP53 mutated } \\
\hline ins/ins & $125 / 35$ & 1.0 \\
\hline ins/del & $210 / 80$ & $1.31(0.82-2.09)$ \\
\hline del/del & $101 / 33$ & $1.18(0.68-2.06)$ \\
\hline ins/del+del/del & $311 / 113$ & $1.27(0.82-1.97)$ \\
\hline \multicolumn{3}{|l|}{ TP53 wildtype } \\
\hline ins/ins & $125 / 23$ & 1.0 \\
\hline ins/del & $210 / 49$ & $1.17(0.66-2.06)$ \\
\hline del/del & $101 / 40$ & $1.89(1.03-3.46)$ \\
\hline ins/del+del/del & $311 / 89$ & $1.40(0.83-2.38)$ \\
\hline \multicolumn{3}{|l|}{ Adenocarcinoma } \\
\hline ins/ins & $125 / 38$ & 1.0 \\
\hline ins/del & $210 / 77$ & $1.29(0.79-2.09)$ \\
\hline del/del & $101 / 43$ & $1.46(0.84-2.51)$ \\
\hline ins/del+del/del & $311 / 115$ & $1.34(0.85-2.12)$ \\
\hline \multicolumn{3}{|l|}{ Squamous cell } \\
\hline ins/ins & $125 / 45$ & 1.0 \\
\hline ins/del & $210 / 93$ & $1.18(0.75-1.86)$ \\
\hline del/del & $101 / 51$ & $1.48(0.88-2.50)$ \\
\hline ins/del+del/del & $311 / 144$ & $1.28(0.83-1.95)$ \\
\hline \multicolumn{3}{|l|}{ Large cell } \\
\hline ins/ins & $125 / 21$ & 1.0 \\
\hline ins/del & $210 / 31$ & $0.90(0.49-1.65)$ \\
\hline del/del & $101 / 18$ & $0.92(0.45-1.90)$ \\
\hline ins/del+del/del & $311 / 49$ & $0.91(0.51-1.60)$ \\
\hline
\end{tabular}

*Four controls and five cases failed to yield genotype results.

${ }^{\dagger}$ Odds ratios were calculated in an unconditional logistic regression model using the common genotype as reference (1.0). All ORs were adjusted for age, sex and smoking (pack-years). $P$ values (two-sided) were obtained from the same logistic regression by comparing frequency of heterozygotes or variant homozygotes with common homozygotes.CI, ${ }^{\ddagger} 95 \%$ confidence interval.

Am. J. Biomed. Sci. 2010, 2(2), 121-128; doi: 10.5099/aj100200121 @ 2010 by NWPII. All rights reserved. 


\section{Discussion}

There was no main effect of the CASP8 ins/del polymorphism on NSCLC but male subjects with homozygote $\mathrm{del} / \mathrm{del}$ genotype had an increased risk of NSCLC. This is in contrast to the proposed protective effect of the del variant in lung cancer patients from the Chinese population [5]. Whether these sex differences are attributed to the inheritance of the del allele or differences in level of exposure to tobacco carcinogens is not known since men and women have different smoking habits. In our study population the cumulative smoking dose in terms of total life time pack-years was significantly higher in male cases and controls compared to female cases and controls (data not shown). Furthermore, sex differences in occupational exposure to carcinogens and life style factors such as alcohol consumption and diet may also affect the risk. Some studies suggest gender differences in lung cancer susceptibility being higher for females [14] whereas others do not support such a hypothesis $[15,16]$.

Another apoptotic pathway is regulated by the TP53 tumor suppressor gene and TP53deficient cells are resistant to apoptosis. There are variable reports on the effects of genetic variants of TP53 gene in relation to lung cancer susceptibility [17]. Furthermore, the interaction between CASP8 and TP53 genetic alterations has not been investigated. While somatic mutations of CASP genes are rare in lung tumors [18], TP53 mutations are common and occur early during lung tumorigenesis [19]. The lack of any effect of the CASP8 polymorphism in a tumor genetic background where TP53 was somatically mutated could suggest a lack of interaction between TP53 alterations and CASP8 ins/del polymorphism.

The differential effects of this polymorphism in conferring susceptibility to lung cancer between the Asian and the European Caucasian populations could be due to several reasons. Firstly, genetic factors may vary between the Asian and the Caucasian populations as it is evident from several studies that the frequency of the del variant is almost two-fold higher in Caucasians [6,7]. Secondly, it is possible that exposure to the environmental factors such as indoor pollutions, infectious agents and life style factors may be different in the two populations [20]. Thirdly, the associations observed in the Chinese population may be unique to this study population and may not be replicated in other populations.

With the sample size of 882 individuals we had more than $80 \%$ power to detect an OR of 1.5 assuming co-dominant and recessive models, a two-sided test using $\alpha=0.05$ and a variant allele frequency of 0.47 observed in our population. This study included only subjects of Norwegian origin and the Norwegian population has a homogeneous European ancestry. It is therefore unlikely that the lack of any significant association is attributable to bias or population stratification.

In conclusion, our results complement the results obtained from colon, breast and prostate cancer studies in various European populations indicating no role for CASP8 variants as cancer susceptibility markers in Caucasian populations.

\section{Acknowledgements}

The collaboration of Dr Lodve Stangeland, Haukeland University Hospital, Bergen, is acknowledged. This project was supported by The Norwegian Cancer Society.

\section{Conflict of interest statement}

We declare that no conflict of interest exists for any of the authors.

\section{References}

1. Schwartz, AG.; Prysak, GM.; Bock, CH.; Cote, ML. The molecular epidemiology of lung cancer. Carcinogenesis 2007, 28, 507518.

2. Salvesen, GS.; Riedl, SJ. Caspase mechanisms. Adv Exp Med Biol 2008, 615,1323.

3. Hussain, SP. and Harris, CC. p53 biological network: at the crossroads of the cellularstress response pathway and molecular carcinogenesis. J Nippon Med Sch 2006, 73,54-64.

(C) 2010 by NWPII. All rights reserved. 
4. Pfeifer, GP.; Denissenko, MF.; Olivier, M.; Tretyakova, N.; Hecht, SS.; Hainaut, P. Tobacco smoke carcinogens; DNA damage and p53 mutations in smoking-associated cancers. Oncogene 2002, 21,7435-7451.

5. Sun, T.; Gao, Y.; Tan, W.; Ma, S.; Shi, Y.; Yao, J.; Guo, Y.; Yang, M.; Zhang, X.; Zhang, Q.; Zeng, C.; Lin, D. A six-nucleotide insertion-deletion polymorphism in the CASP8 promoter is associated with susceptibility to multiple cancers. Nat Genet 2007, 39,605-613.

6. Haiman, CA.; Garcia, RR.; Kolonel, LN.; Henderson, BE.; Wu, AH.; Le, ML. A promoter polymorphism in the CASP8 gene is not associated with cancer risk. Nat Genet 2008, 40,259-260.

7. Pittman, AM.; Broderick, P.; Sullivan, K.; Fielding, S.; Webb, E.; Penegar, S.; Tomlinson, I.; Houlston, R.S. CASP8 variants D302H and $-6526 \mathrm{~N}$ ins/del do not influence the risk of colorectal cancer in the United Kingdom population. Br J Cancer 2008, 98,1434-1436.

8. Frank, B.; Rigas, SH.; Bermejo, J.L.; Wiestler, M.; Wagner, K.; Hemminki, K.; Reed, M.W.; Sutter, $\quad$ C.; Wappenschmidt, B.; Balasubramanian, S.P.; Meindl, A.; Kiechle, M.; Bugert, P.; Schmutzler, R.K.; Bartram, C.R.; Justenhoven, C.; Ko, Y.D.; Bruning, T.; Brauch, H.; Hamann, U.; Pharoah, P.P.; Dunning, A.M.; Pooley, K.A.; Easton, D.F.; Cox, A.; Burwinkel, B. The CASP8 -652 6N del promoter polymorphism and breast cancer risk: a multicenter study. Breast Cancer Res Treat 2008,,111,139-144.

9. Zienolddiny, S.; Ryberg, D.; Maggini, V.; Skaug, V.; Canzian, F.; Haugen, A. Polymorphisms of the interleukin-1 beta gene are associated with increased risk of non-small cell lung cancer. Int J Cancer 2004,109,353356.

10. Engels, E.A.; Wu, X.; Gu, J.; Dong, Q.; Liu, J.; Spitz, M.R. Systematic evaluation of genetic variants in the inflammation pathway and risk of lung cancer. Cancer Res 2007, 67,6520-6527.

11. Zienolddiny, S.; Campa, D.; Lind, H.; Ryberg, D.; Skaug, V.; Stangeland, L.B.;
Canzian, F.; Haugen, A. A comprehensive analysis of phase I and phase II metabolism gene polymorphisms and risk of non-small cell lung cancer in smokers. Carcinogenesis 2008, 29,1164-1169.

12. Ekstrom, P.O.; Khrapko, K; Li-Sucholeiki, X.C.; Hunter, I.W.; Thilly, W.G. Analysis of mutational spectra by denaturing capillary electrophoresis. Nat Protoc 2008, 3,11531166.

13. Lind, H.; Ekstrom, P.O.; Ryberg, D.; Skaug, V.; Andreassen, T.; Stangeland, L.; Haugen, A.; Zienolddiny, S. Frequency of TP53 mutations in relation to Arg72Pro genotypes in non small cell lung cancer. Cancer Epidemiol Biomarkers Prev 2007, 16,20772081.

14. Mollerup, S.; Ryberg, D.; Hewer, A.; Phillips, D.H.; Haugen, A. Sex differences in lung CYP1A1 expression and DNA adduct levels among lung cancer patients. Cancer Res 1999, 59,3317-3320.

15. Cook, M.B.; Dawsey, S.M; Freedman, N.D; Inskip, P.D.; Wichner, S.M.; Quraishi, S.M.; Devesa, S.S.; McGlynn, K.A. Sex disparities in cancer incidence by period and age. Cancer Epidemiol Biomarkers Prev 2009, 18,11741182.

16. Freedman, N.D.; Leitzmann, M.F.; Hollenbeck, A.R.; Schatzkin, A.; Abnet C.C. Cigarette smoking and subsequent risk of lung cancer in men and women: analysis of a prospective cohort study. Lancet Oncol 2008, 9,649-656.

17. Whibley, C.; Pharoah, P.D.; Hollstein, M. p53 polymorphisms: cancer implications. Nat Rev Cancer 2009, 9,95-107.

18. Shivapurkar, N.; Toyooka, S.; Eby, M.T.; Huang, C.X.; Sathyanarayana, U.G.; Cunningham, H.T.; Reddy, J.L.; Brambilla, E.; Takahashi, T.; Minna, J.D.; Chaudhary, P.M.; Gazdar, A.F. Differential inactivation of caspase-8 in lung cancers. Cancer Biol Ther 2002, 1,65-69.

19. Shimmyo, T.; Okada, A.; Hashimoto, T.; Kobayashi, Y.; Miyagi, Y.; Ishikawa, Y.; Nakagawa, K.; Osada, H.; Tsuchiya, E. Etiologic value of p53 mutation spectra and 
differences with histology in lung cancers. Cancer Sci 2008, 99,287-295.

20. Zhang, J.J. and Smith, K.R. Household air pollution from coal and biomass fuels in
China: measurements; health impacts; and interventions. Environ Health Perspect 2007, 115,848-855. 